\title{
Problematics of Saints Cult in Works of Jadidist-Theolologians of the Late XVIII and the Early XX cc.
}

\author{
E.Kh. Seidametov \\ Department of History of the State Budget Educational Institution \\ of Higher Education of the Republic \\ of Crimea Crimean Engineering Pedagogical University \\ Sevastopolska str., 8, Uchbovy alley, 295015, Simferopol, Russian Federation \\ Crimean Scientific Center of the Institute of History named after Sh. Marjani of the \\ Academy of Sciences of the Republic of Tatarstan \\ 7, Baturin St., Kazan 420111, Russian Federation
}

The article deals with the analysis of the problems of the cult of saints in the religious views of the greatest Tatar Jadid - theologians of the late $18^{\text {th }}$ and the early $20^{\text {th }}$ centuries. The research aims to investigate the views of Abdennacer Kursawe, Shihab Al-din al-Marjani, Galimjan Barudi, Rizaetdin Fakhretdin, Musa Jarullah Bigiev. The scholars searched the reasons for the crucial decline that involved the Muslim peoples, they believed that the only way out was the correction of Muslim beliefs, the refusal of religious innovations and the return to the Holy Quran and Sunnah. They criticized various manifestations of ignorance and superstition as well as some traditions that, in their opinion, were contrary to the canons of Islam and prevented the progress of Muslims.

The Jadids supported the reform of the education system, the study of worldly sciences, the borrowing and use of global scientific and technological and other achievements.

The similar position of Tatar theologians contributed to the formation of Islamic cultural values and present new ways for Russian Muslims to unify to the achievements of the world civilization.

Keywords: jadidism, cult of saints, tasawwuf (sufism), bid'a (innovation), tawhid (monotheism), kalam

\section{Introduction}

Jadidism as a social and political and intellectual movement among the Turkic Muslims of the Russian Empire in the late $18^{\text {th }}$ and early $20^{\text {th }}$ centuries is studied in many researches. In recent decades many works have been published show-

(C) Seidametov E.Kh., 2019.

(c) (i) This work is licensed under a Creative Commons Attribution 4.0 International License

https://creativecommons.org/licenses/by/4.0/ 
ing the influence of Jadidism onto the religious, intellectual, social and political life of the Muslim population of Russia. At the same time the question of the attitude of the Russian ulama-Jadids to the cult of the saints, which was spread among the majority of Turkic-Muslims, is not widely investigated.

Prominent representatives of this movement - Abdennacer Kursawe, Shihab Al-din al-Marjani, Galimjan Barudi, Rizaetdin Fahretdin, Musa Jarullah Bigiev Marjani - were supporters of innovative ideas in the interpretation of Muslim religious doctrine. The peculiarity of their appeal was the rejection of innovations in religion and a return to the Qur'an and Sunnah, as well as the opinion of the companions of the Prophet Muhammad. They opposed many existing traditions and, in their opinion, contradicted the doctrines of Islam, primarily against the cult of saints, which was especially revered among ordinary peoples. Kalam was condemned and innovations in the cult sphere were not welcomed: charging for reading the Qur'an, saying a prayer, and performing any rituals. At the same time, they encouraged achievements in the field of mutual relationship between peoples (economic, political, international relations, trade deals, participation in companies, publishing newspapers, teaching secular sciences, etc.). Such behavior of the Tatar ulama, on the one hand, contributed to the enforcing of Islamic cultural values, and on the other hand, enabled new ways for Russian Muslims to organic familiarization to the achievements of world civilization. All this allows considering them to be outstanding representatives of Islamic enlightenment in the late $18^{\text {th }}$ and the early 20th centuries, who thoroughly analyzed a new vision of the development of Muslim intellectual tradition.

\section{A. Kursawe about the concepts bid'a, tasavwuf, tawhid}

The founder of the new movement among the Tatars was Abdennacer Kursawe (1776-1812). In 1804 he appealed to Muslims to reject innovations in religion (bid'a), and return to the Qur'an, Sunnah and the opinion of the companions of the Prophet Muhammad (peace be upon him) (Al-Kursavi, 2005, 161).

In the book "Guiding Peoples to the Path of Truth", A. Kursawe studies such notions as bid'a, tasawwuf, tawhid, which sufficiently fully illustrates his attitude to innovations in religion that are reprehensible; spiritual and moral perfection of a Muslim, which can be achieved only by following the Divine Law and the Sunnah; monotheism, in which there is no place for intermediaries among the deceased saints and righteous peoples (Al-Kursavi, 2005, 144-177).

Bid'a is condemned when deviation from the basic principles of Islam is committed. For Kursawe, it is to follow the Book of Allah, the Sunnah of the Messenger of Allah, the ijma's community and qiyas (Al-Kursavi, 2005, 144). He condemned philosophy (falsafa) and Kalam, classifying them as prohibited innovationsand he considered them to be wastefulness (Al-Kursavi, 2005, 154); he criticized innovations in the cult sphere: charging for reading the Qur'an or dhikr, prayers (du'a), prayers (salad) or any other rituals, which, in his opinion, was "a 
confession by personal opinion, without a legal basis" (Al-Kursavi, 2005, 145, 146). According to M. Kemper's opinion, Kursawe can easily be considered as a critic of the cult of saints (Kemper, 2008, 371). On the other hand, Kursawe welcomed the innovations in the field of secular sciences and relations between peoples (economic, political, international and others) (Khakimov, 2010, 129).

The meaning of tasawwuf, according to Kursawe, is "to clear the heart from bad behaviour, worldly concerns, and [bringing it] into the correspondence with the natural pattern [of human nature]. So that [a man], after his deprivation of bad qualities, he can acquire moral qualities, and his cares become more elevated, and he will focuse on worship and follow the Prophet in Sharia, and his carnal soul (nafs) will refuse his passions, - became a Sufi"(Al-Kursavi, 2005, 170). But the tasawwuf must certainly be within the Sharia. According to the words of Imam Malik, he says that one who practices fiqh but does not study tasawwuf becomes a wicked person (fasik), and one who practices tasawwuf but does not learn fiqh becomes a polytheist (zindik). Only one who combines both of these abilities can understand the truth (Al-Kursavi, 2005, 173).

According to Kursawe, the true tawhid (monotheism) is that a person considers all circumstances created by Allah and ceases to pay attention to intermediaries, he sees intermediaries as subordinates who do not have their own authority. And if a believer ceases to pay attention to reasons and intermediaries and he sees good and evil only from the Almighty, a man neither fears nor hopes except for Him, then he is a true Tawhid who understands the truth. For the true believer the reasons disappear due to his faith to the First Cause, he is engaged into tawhid andintermediaries no longer exist for him (Al-Kursavi, 2005, 175-177).

Thus, according to Kursawe, a true believer is one who has completely and thoroughly connected his heart with the Creator; a man trusts and meekly betrays himself to the decision of Allah; he refuses any intermediaries (including through awliya, asking them to intercession); a believer worships only Allah alone and does not following base passions (Al-Kursavi, 2005, 175-179).

The prominent theologian of the Islamic world of the 19th century alMarjani expressed his opinion about Kursawe in such a way: "Truly he was a person who did not delight the gaze of time for five hundred years, neither close nor far, and no one was known who could be compared with him, he was not heard of anyone in the far ends of the world, nor in the neighbors who could come close to him in his brilliant knowledge of [sciences from the field] rational (ma'kul) and traditional (mankul), mastery in particular matters and the foundations of [creeds], generosity in [matters] of disagreement and mazhabs, the ability to conduct polemics and literature, the memorization of hadiths, exceptional knowledge of their varieties and sections, the strength of his ijtihad and the superiority of extraction [motive in logical analysis]. Along with this, he possessed a sharp mind, a refinement of thought, he was able to motivate (husnta'lil), possessed sound judgments (nazar), much worship, plenty of fiqh, perfect abstinence, utmost piety, relentless observance of the Sunnah, following the right path, moving away from unauthor- 
ized innovations, removal from base passions, preference for the path of the early generations (Salaf), following the true successors. He tried his best to win the Sharia and fight for him, revive the Sunnah and protect it, Allah knows about this, may He reward him, He is glorified, for his efforts. He perfectly instructed peoples telling the truth, without fearing for Allah's reproaches of the blasphemer'(Al-Marjani, 2005, 226).

After the death of Kursawe, Sh. Marjani (1818-1889) became one of the most important followers and distributors of his teachings. His attitude to the cult of saints was also disapproving. From the bibliographic information collected by Shahar Sharaf, we learn that al-Marjani, observing in Bukhara excessive veneration of graves and a cry for help from the dead, said: "Even the people of our village have more moral principles than they have. In our village, they ask for help from Allah and utter takbir and azan"(Marjani,2015, 48-49; Marjani, 2008, 68).

It is worth mentioning that in general, the problems of the cult of saints did not particularly interest Kursawe and Marjani. Apparently, this was due to the fact that, firstly, the cult of saints (azizler, khuzhalar) moved from Central Asia into the Volga-Ural region and it was not widespread. R. Fakhretdin connects this with the educational activities of the Dagestan scholar Muhammad b. Musa al-Kuduki: "The fact that the Muslims of our region are relatively far from the innovations related to the dead and funerals that are widespread in many Islamic countries, and they were not familiar with such phenomena as dervishes living near graves and eating alms and vows of the peoples, there is a belief that a great merit belongs to Kuduki. Innovations related to the graves began since the relations with the scientists of Dagestan stopped. There is no doubt that our scientists, who are trying to eliminate such innovations as commemoration of the third, seventh, fortieth day and obit, are students of the students of Muhammad Kuduki"'(Khabibullin, 2015, 34; Shura 1914, No. 1, 1,2). Secondly: at that time the most relevant and discussed issues among the Volga Ulama were issues related to night prayers ('isha) in the northern latitudes, general Friday prayers, ijtihad and Taklid, etc. (Kemper, 1999, 166-167; Shagaviev2016, 44).

Over time this topic begins to be widely discussed by such famous Russian theologians as G. Barudi, R. Fakhretdin, M. Bigiev, and others.

\section{G. Barudi about the ban of sacrifice on the graves, to utter prayers to the deceased aulia for help, dedicating vows to them}

Galimjan Barudi (1857-1921) - the founder of the largest and most prestigious madrasah in Kazan, Muhammadiya, one of the inspirers and ideologists of Jadidism in Russia, the mufti of the Spiritual Administration of Muslims of Inner Russia and Siberia (1917-1922).

G. Barudi opposed many traditions that existed among the peoples who opposed the doctrines of Islam - primarily against the cult of saints. On the pages of the Shura and Ad-din Val-adab magazines the scholar repeatedly writes about the 
inadmissibility of treating saints as intermediaries, making sacrifices on graves, and contacting with du'a (prayers) for the intercession of the dead auliya (Khabibullin, 2015, 34).

So, in tafsir to ayat 165 from the al-Bakar surah "Among peoples there are those who make equals to Allah and love them just as they love Allah," Barudi wrote that most peoples tend to worship what can be seen openly with their own eyes. For this reasonthey are excessive, believe and become attached with their hearts to what can be seen, especially it refers to the graves of the righteous and holy peoples. Some of them when they get into trouble, break the rules and begin to ask for their help, expect some kind of support and salvation from them, and sometimes they begin to worship them, openly commit polytheism (shirk). There are few peoples who are impartial and understand the truth.

According to Barudi, true believersare those who have known Allah properly. They do not equate Him to anyone, love the righteous, but do not exalt them to the degree of Allah, they do not endow them with the qualities inherent in Allah and do not exalt them to worship but they believe that they are worthy slaves of the Almighty who possess nothing and need Allah in everything. This is the essence of true faith and correct belief which is free from polytheism (Khabibullin, 2015, 34.35; Ad-dinval'-adab, 1916, No. 13, 347).

In tafsir ayat 168 of the al-Bakar Sura "O people! Eat on the earth what is permissible and pure, and do not follow the footsteps of Satan. Verily, he is to you an open enemy" Barudi wrote that visiting the graves of Aishabika by ignorant peoples of Bulgar as well as other graves, dedicating vows and sacrifices to them also belong to the mentioned "footsteps of the devil" and innovations that have no foundations in religion. Every believer who is striving to maintain his creed should beware of such dubious things. Innovations, unbelief and polytheism go through very subtle ways through which the devil, embellishing such things, deceives peoples by misleading them (Khabibullin, 2015, 35; Ad-dinval'-adab, 1916, No. 13, 380).

Barudi believed that visiting graves is a permissible action, but only for the purpose of edification in order to think over death and future life as well as to appeal to prayers for deceased Muslims. Such a visit corresponds to the Sunnah. Other kinds, for example, such as sacrifice on graves in honor of the dead saints, asking for their help, etc., is a terrible innovation that contradicts the Sunnah and, in some extent. It is considered to beidolatry.

In the early years of Islamthe messenger of Allah Muhammad forbade visiting graves fearing that Muslims would return to polytheism, but after they established themselves in their religion, the ban on visiting graves was rejected (Khabibullin, 2015, 35, 36; Ad-dinval'-adab, 1913, No. 24, 742-744).

Barudi opposed not only the cult of saints, but also other traditions, especially common among Sufis, who were positioned by him as innovations in religion: the practice of reciting some prayers (not confirmed in the Sunnah), loud recitation of ayat al-Kursi and some dhikr (praises) after collective prayers in 
mosques, which was considered to be obligatory among the common peoples, the calling Allah the names that are not confirmed in the Qur'an, the Sunnah and others (Khabibullin, 2015, 36, 38; Batyr, 2017).

\section{R. Fakhretdin about the spiritual causes of the Muslim decline}

G. Barudi had a like-minded person in matters of clearing Islam from innovations. It was Rizaetdin Fakhretdin (1859-1936), a famous Tatar theologian, writer and enlightener, oriental scholar, the Mufti of the Central Spiritual Administration of Muslims of Russia (1921-1936). Like Barudi and other Ulama Jadids, he harshly criticized pagan remnants in the traditions of the peoples (which separated and not united Muslims) and opposed the worship of saints, guardians, as well as the so-called "masters of the mountain" and "holy springs" (Khabutdinov, 2010). P. Fakhretdin repeatedly mentioned about the necessity to "return to pure Islam". The "clearance" of Islam from tribal religious customs as well as later innovations was, in his opinion, an objective condition for uniting Muslims around the world (Gafarov, 2014, 501). Ideas of R. Fakhretdin and other Jadids correlate with the views of al-Sirhindi, Ibn Taymiyyi, ibn al-Qayim al-Dzawziyyi, Dzamalad-Dinaal-Afghani, Muhammad Abdoiand other religious peoples who also believed that the return of believers to the Qur'an and Sunnah and their unification monotheism (tawhid) will contribute to the consolidation of Muslims.

In conclusion to his work "Ibn Taymiyyah" R. Fakhretdin reflects on the causes of progress and regress, the rise and extinction of the nations. He concludes that the core of everything that happens in the world: revolutions, political, economic, scientific and literary disputes in public life - is a belief. "Difficulties and conflicts of peoples, unions and disagreements, problems and difficulties in life are all the reasons of religious views. R. Fakhretdin thinks: "Under their leadership the most insignificant nations rise, and the strongest fall into decay and even disappear, and only some names remain in documents and some monuments for archaeologists' disputes" (Fakhretdin, 2018, 216). Not only the fate of nations, nations, tribes and clans, but also a fate of a single person depends on the faith.

He examines the example of Arabs who due to Islam, managed to free from the state of jahilin (primitive rudeness and ignorance when paganism reigned) and backwardness at the forefront of world history. "They overcame the mountains and spread around the world, began to rule capturing countries and cities. Having become heirs of the states of Caesar and the Shah, they made the surface of the earth an arena of action ... the whole world revived under the Islamic influence "(Fakhretdin, 2018, 216). He compares their revivalin the Islamic world with the movement of the conveyor inside a huge factory. He sees the reason for these extraordinary changes and amazing activity in a change in creed (Fakhretdin, 2018, 218).

He also argues that if Muslims maintained a healthy Islamic belief, then Europeans who possessed schools and scientists, artisans, researchers and inventors, factories and plants, architects and engineers, doctors and professors, culture in its 
true meaning - all it would appear in the Islamic world. However, he regrets the later Muslims did not follow the way of the early ones. They followed the belief of religion traders, on its behalf they began to prohibit the crafts and professions which were necessary for the happiness and life of peoples. Contrary to the Qur'an, they endowed peoples with righteousness and holiness - they made them Kaaba for themselves. Considering them to be "master of fate", "assistants of creations" and "poles of the Universe" they began to appeal to them with pleas for help and show humility before them. As a result of such a distorted belief, the Islamic world became like an abandoned factory which fell into inactive idleness (Fakhretdin, 2018, 218, 219).

The inaction, ignorance and superstition that spread in the Islamic world, according to R. Fakhretdin, led to the fact that Muslims began to lose "inherited wealth from their predecessors and beautiful countries like Paradise." However, instead of rethinking and learning a lesson from their position, waking up and following the Qur'an and the Sunnah of the prophet, they turned their hearts "to the graves - the Kaaba of their needs, and to the souls of the dead that were revered as deities as well as to ishanas - living idols". As a result, they received only privations and hardships (Fakhretdin, 2018, 220, 221).

R. Fakhretdin compares the current state of Muslim civilization with the Christian world, and says that the spiritual disease which previously dominated the Christians, passed on to Muslims. "The names of the saints and the righteous became a source of food and a means of life. Their graves along with the surrounding areawere filled with mujawirs ${ }^{1}$ eating donationsand sellers of karamat.

There appeared, although under a different name, but with the same essence, the estate of "monks". The names of the nobles became a matter for the idle speeches" (Fakhretdin, 2018, 222).

The scientist does not deny the holiness of the prophets and respect for the righteous, but he believes that showing respect for them should be without excessiveness and exaggeration in accordance with the spirit of the Quran and Sunnah. "Human preferences and feelings are unsuitable for being taken as an example and customs shouldn't be treated as a guide to action. The only criterion for respect must be the Book and the Sunna", says R. Fakhretdin (Fakhretdin, 2018, 223, 224).

Like a doctor, exposing the spiritual ailments of society (ignorance, superstitions, grave worship, idleness, begging), he compares his contemporaries with righteous predecessors (Salafs), who, unlike the first ones, followed the precepts of religion, managed to create a high civilization (Fakhretdin, 2018, 225, 226). He says: "There are so many begging people who filled the streets - they wander around and sitting up all the honorable and empty seats. But this heavy burden for the nation is not enough for anyone. In order to suck out the wealth of the people, like leeches, things were created in many places (and they are still being created)

\footnotetext{
${ }^{1}$ Mujawir - caretaker for the graves of saints.
} 
like the "Mountains of the Lords" and the "Spring of the Righteous". The examples of these facts are widely-known. Now look at the Salaf, then look at the late Muslims! The difference between them is so great that it's even hard to understand if they have something in common. Now the old lions were replaced by monkeys, the thrones of true scientists were occupied by hangers for suits. Everyone with insight sees and knows this, his conscience will not allow this not to be confessed" (Fakhretdin, 2018, 228).

Describing the regress of the Islamic nation, R. Fakhretdin said that Muslims, who developed very fast fell into stagnation under the influence of perverse beliefs and ceased to develop losing their countries. "Schools lost their reputation, scientists were no longer respected. Each lazy fool was appointed to the post of ishan, and each madman - to the post of qutb. The Islamic world from one end to the other became completely fragmented, impoverished and careless. India, the former golden treasury, and Turkestan, the former source of knowledge, were victimized by the wrong creed. Marrakech and Andalusia, Egypt and Turkmenistan perishedbeing the victims of this belief. Nothing left from knowledge and scientists of salafists. The place of deep piety and sincerity was taken by hypocrisy and pretense, boasting and frivolity. Very young and healthy people, like ifrit ${ }^{2}$, pretended to be ishanas, they picked up staves and rosaries and started wandering around idly - walking from house to house, sucking out the wealth of Muslims like leeches. Unworthy people were assigned the high posts and became an instrument of oppression, making fatwas on behalf of religion in accordance with the vagaries and folly of every tyrant and despot. Neither name nor self-esteem and love for the nation left" (Fakhretdin, 2018, 225). According to the scientist, the result of all these factors was the economic and political crisisas well as the degraded situation of Muslims. As a result, they plunged into the abyss of hopelessness and destitution (Fakhretdin, 2018, 226).

In the final part of the book R.Fakhretdin asks a rhetorical question: "Do Muslims wish a happy existence and a prosperous future? Or do they prefer living like slaves walking the streets in search of work with a broom and an ax in their hands..." (Fakhretdin, 2018, 229). Then he himself answers: "If not, then they should understand Islam as salafs understood it, and bring this understanding to their daily existence. It is much more useful to build schools instead of erecting buildings on graves; the money given to the Mujawirs at the graves spend onto the knowledge; things spent on travels to holy springs and graves send to the training of shakirs and raise the children of the nation, opening houses of charity and mer$\mathrm{cy}$, to ensure the life of weak Muslims. Giving a religious atmosphere to secular and mundane matters and placing in religion what is not transmitted from the Noblest Messenger is undoubtedly a crime against faith and a manifestation of immoderation in it" (Fakhretdin, 2018, 229).

\footnotetext{
${ }^{2}$ Ifrit - a strong man among the genies.
} 
Thus, in his conclusion to the book "Ibn Taymiyah" R. Fakhretdin states in detail his vision regarding the complex crisis that gripped the Muslim ummah, the main reason for which, in his opinion, is the corruption of beliefs - deviation from the path of the Quran and Sunnah to ignorance and polytheism, one of the most striking manifestations of which was the cult of saints.

\section{Bigiev about ishanism}

One of the main representatives of Jadidism was the outstanding scholartheologian Musa Jarullah Bigiev (1873-1949). Like many other representatives of Jadidism, in his theological views he appealed to the period of righteous predecessors and opposed various innovations in religion.

According to T. Zarkone, the attitude of M. Bigiev to Sufism was characterized by duality. On the one hand, he was a supporter of the sufi community (a system of mansions - "khanaka"), on the other hand, he criticized ishans, i.e. sufi clerics. The word "ishan" could mean the leader (sheikh) during spiritual mystical self-improvement or the keeper of the saint's grave, praying for his intercession at the request of the pilgrims, the healer or even theamulet makers (Zarkone, 1997).

Ishans were perceived by M. Bigiyev as carriers of ignorance and the main reason of decay on the development of Islam (Khakimov, 2010, 120). In his work, "Fasting in the Long Days" Musa Jarullah Bigiev writes: "In recent centuries under the influence of: 1) ascetic fakihs, 2) ignorant mufassir interpreters, 3) stupid Muhaddis interpreters, 4) false preachers, 5) insidious praisers, 6) venal poets, 7) sufi drones, 8) flattering scholars, 9) sheikhs of sufi orders, 10) prophesied intercessors, 11) people using hashish, 12) teachers who killed their lives and religion in vain in idle talk, 13) the inhabitants of the graves, heads of the wakufs, who fully devoted their lives to an idle accumulation of material wealth, 14) petty scribblers who plunged Islamic morality into shame and misfortune, 15) khatibs, weekly explaining to believers various lies and fatal deceit, 16) madrassas, that are destructive for being, brain and hearts, 17) mosques, which instead of clearing people's hearts, lightening their souls and giving spiritual strength, they do theopposite, 18) people who turned into religious use rituals and canons established by the Legislator to bring great benefit to people, 19) those crimes that take place in the family circle, in the inner temple, under the guise of a religious tradition - under the influence of all this stuff in the world of Islammorality was completely corrupted, any perfection was interpreted and explained in such a way that it turned into its opposite. And all the destructive qualities were presented as an element of faith and an absolute good" (Bigiev, 2005, 325, 326).

Other dzadids expressed the similar neglectful characteristics to ignorant ishans (Guseva, 2013, 78). For example, M. Bigiev's elder brother Zikhir Bigiev (1870-1902) in his book "Travel to Maverannahr" describes in detail adventures with donations (sadaka) that distorted and perverted Islamic ideas about alms and charity: "Charity, alms are considered by Muslims to be the highest manifestation 
of kindness. The Divine Law allows alms for the unfortunate and destitute to give alms for the edifying purpose, but it prohibits helping those who became poor because of their laziness"'(Zarkone, 1997). He calls the estate of guardian ishans of graves who speculated on human hardships and misfortunes "nazrkhur" (almseaters, generosity) (Zarkone, 1997).

Zarkone T. in his article "Sufism in the Tatar world at the beginning of the $20^{\text {th }}$ century" subdivides ishans into two categories - "blacks" and "whites". The first ones deceive the people enriching themselves at their expense. For the purpose of personal enrichment, they held festive religious rites with rich people, they opposed enlightenment and education. They represented the image of an ignorant village sufi who was content with the post of healer or guardian of the grave. The "white" ishans whom he called sheikhs were knowledgeable people, knowledgeable in religious affairs, among them there were educated sufis and great scholars, whose activities did not contradict the Quran and the Sunnah. Ignorant ishans gathered their followers near the graves of some saint to perform various kinds of rituals asking patronage of the saint for healing from disease, protection from evil, etc. Educated sheikhs gathered their students in madrassas and taught them religion based on the Qur'an and Sunnah (Zarkone, 1997).

\section{Conclusion}

Late $18^{\text {th }}$ and the early $20^{\text {th }}$ centuries are characterized by the process of revival of the social and theological thought of the Tatars. The publication in 1773 of the Decree of the Synod "On Tolerance" led to the beginning of this process. In search of knowledge, the Tatar shakirs went to Bukhara, Samarkand, Kabul, Istanbul, Beirut, Cairo, Mecca, Medina, etc. (Gafarov, 2014, 145). Therethey got the opportunity to get acquainted with the religious heritage of such famous religious figures as as-Sirhindi, Shah Valiullah, ibn Taymiyyah, ibn al Qayyim alJawziyyah, Mehmed Bergevi, Muhammad ibn Abd al-Wahhab, Jamalad-Dina alAfghani, Muhammad Abdo, Muhhamad Rashid Rida, etc. Undoubtedly, their views shaped the worldview, contributed to the revival and enrichment of the theological thought of the Tatars (Adigamov, 2014, 558, 574). Under the influence of these ideas, the Jadid (innovative) movement was formed, which sought the ways out of the existing spiritual and social and economic crisis of the Muslims of Russia and the entire Islamic world and saw them in the return of Muslims to the Qur'an and Sunnah.

In their works the Jadids turn to the era of righteous predecessors (Salafs) and see in it as an example of an ideal society to which the ummah should strive. Kalam and its theological strata, various rites and cults that have no basis in Sharia, are regarded by them as bid'a and rejected. Referring to the hadith: "Every innovation is a delusion, and every delusion is on fire!" (Al-Kursavi, 2005, 146), innovations in religion are censured. The cult of saints and the institution of ishans, the guardians of the graves of saints, were considered one of the manifes- 
tations of the corruption of beliefs caused by ignorance and without any foundation in religion. The cult of saints is represented as polytheism by many Jadids, and ishanism as the main reason of decay in the development of Islam.

If innovations in religion were condemned, then the study of secular sciences, the borrowing of Europeans of modern scientific, technological and other achievements by Muslims were, in the view of the Jadids, an important condition on the path to Muslim progress. A correct Islamic belief along with the world scientific and technological achievements of our time, in their opinion, should have led Muslims out of the abyss of ignorance and humiliation to the path of knowledge and greatness, revived the social and economic life of the Tatar society (Fakhretdin, 2018, 226, 229).

\section{СПИСОК ЛИТЕРАТУРЫ}

[1] Абу-н-Наср 'Абд ан-Насир ал-Курсави. Наставление людей на путь истины (ал-Иршад ли-л-‘ибад). Казань: Татар. кн. изд-во, 2005. 235 с.

[2] Хакимов Р. Джадидизм (Реформированный ислам). Казань, 2010. 208 с.

[3] Кемпер М. Суфии и ученые в Татарстане и Башкортостане: исламский дискурс под русским господством. Казань: Российский исламский университет, 2008. $675 \mathrm{c}$.

[4] Шихабаддин б. Бахааддин ал-Газани [ал-Марджани]. Послание «Привлечение внимания современников к очищению сведений об Абу-н-Насре» [Рисала танбих абна ал-'аср 'ала танзих анба Аби-н Наср] // Абу-н-Наср 'Абд ан-Насир алКурсави. Наставление людей на путь истины (ал-Иршад ли-л-“ибад). Казань, 2005. С. 225-233.

[5] Шихабутдин Марджани. Сборник статей, посвященный 100-летию Ш. Марджани, изданный в Казани в 1915 г. / Коллектив авторов - «Татарское книжное издательство», 2015 - (Антология татарской богословской мысли). С. 48-49.

[6] Марджани Ш.. Зрелая мудрость в разъяснении догматов ан-Насафи (Китаб алХикма-ал-балига ал джаниййа фи щарх ал-'акаид ал-ханафиййа) / Шигабутдин Марджани; предисл. И пер. с араб. Д. Шагавиев. Казань: Татар. кн. изд-во, 2008. $479 \mathrm{c}$.

[7] Хабибуллин P.P. Реформаторские взгляды Г. Баруди // Бигиевские чтения: богословская мысль российских мусульман XIX - нач. XX вв.: сборник научных статей. М.: Издательский дом «Медина», 2015. С. 30-38.

[8] Шура, 1914. № 1. С. 1, 2.

[9] Кемпер М. Между Бухарой и Средней Волгой: столкновение абд ан-Насра алКурсави с улемами-традиционалистами // Мир ислама. 1999. № 1/2. С. 163-174.

[10] Шагавиев Д. А. Богословский трактат Шихаб ад-дина ал-Марджани «Назурат алхакк» // Ислам в современном мире. 2016. Т. 12. № 1. С. 41-48.

[11] Ад-дин валь-адаб, 1916. № 13. С. 347.

[12] Ад-дин валь-адаб, 1916. № 14. С. 380.

[13] Ад-дин валь-адаб, 1913. № 24. С. 742-744.

[14] Батыр Р. «Сегодня Галимджан Баруди вряд ли бы прошел аттестацию в ДУМ РТ» // Бизнес-газета. 2017. 25 марта: https://www.business-gazeta.ru/blog/340899.

[15] Хабутдинов А.Ю. Каким должен быть муфтий и улем: пример Ризаэтдина Фахретдина (1858-1936) // Рамазановский чтения. 2010. № 5: http://www.idmedina.ru/books/history_culture/?3434\#_ftnref1. 
[16] Гафаров А.А. Российские мусульмане в контексте общеисламской модернизации (XIX - начало XX вв.). Казань: Изд-во Казан. ун-та, 2014. 564 с.

[17] Фахретдин Р. Ибн Таймийя / пер. с старотат. Ш. Сайф ад-Дин. М.: Форум, 2018. $231 \mathrm{c}$.

[18] Зарконе Т. Суфизм в татарском мире в начале XX века (Муса Ярулла Бигиев и один из полемических аспектов этой проблемы) / Материалы международного симпозиума «Ислам в татарском мире: история и современность», Казань, 29 апреля - 1 мая 1996 г. // https://xn--80ad7bbk5c.xn--p1ai/ru/content/sufizm-vtatarskom-mire-v-nachale-xx-veka.

[19] Муса Джаруллах Бигиев. Избранные труды в двух томах. Т. 1. Казань, 2005. C. 325-326.

[20] Гусева Ю.Н. Ишанизм как суфийская традиция Средней Волги в XX веке: формы, смыслы, значение: Монография / под ред. О.Н. Сенюткиной; под общ. ред. Д.В. Мухетдинова. М.: ИД «Медина», 2013. 214 с.

[21] Адигамов Р.К. Становление и развитие богословской мысли татар: история и тенденции // Вестник РУДН. Серия: История России. 2018. № 3. С. 551-580.

\section{REFERENCE}

[1] Al-Kursavi Abu-n-Nasr 'Abd an-Nasir. Nastavlenie lyudey na put' istiny (al-Irshad li1-'ibad) [The instruction of people to the path of truth]. Kazan': Tatar. kn. izd-vo, 2005. $235 \mathrm{p}$.

[2] Khakimov Rafael'. Dzhadidizm (reformirovannyy islam) [Jadidism (Reformed Islam)]. Kazan': Institut istorii AN RT, 2010. 208 p.

[3] Kemper Mikhael'. Sufii i uchenye v Tatarstane i Bashkortostane: islamskiy diskurs pod russkim gospodstvom [Sufis and scholars in Tatarstan and Bashkortostan: Islamic discourse under Russian rule]. Kazan': Rossiyskiy islamskiy universitet, 2008. 675 p.

[4] Shikhabaddin b. Bakhaaddin al-Gazani [al-Mardzhani]. "Poslanie «Privlechenie vnimaniya sovremennikov k ochishcheniyu svedeniy ob Abu-n-Nasre» [Risala tanbikh abna al-'asr 'ala tanzikh anba Abi-n-Nasr]" [Message "Attracting the attention of contemporaries to the clarifying of information about Abu n-Nasr"]. V Abu-n-Nasr 'Abd an-Nasir al-Kursavi. Nastavlenie lyudey na put' istiny (al-Irshad li-1- 'ibad) [The instruction of people to the path of truth]. Kazan': Tatar. kn. izd-vo, 2005. P. 225-233.

[5] Mardzhani Shikhabutdin. Sbornik statey, posvyashchennyy 100-letiyu Sh. Mardzhani, izdannyy v Kazani v 1915 g. (Antologiya tatarskoy bogoslovskoy mysli) [Collection of articles dedicated to the 100th anniversary of S. Mardzhani, published in Kazan in 1915 (Anthology of Tatar theological thought)], red. 2015. Kazan': Tatarskoe kn. izdvo, 2015. P. 48-49.

[6] Mardzhani Shigabutdin. Zrelaya mudrost' v raz"yasnenii dogmatov an-Nasafi (Kitab alKhikma al-baliga al dzhaniyya fi shcharkh al-'akaid al-khanafiyya) [Mature wisdom in clarifying the dogmas of an-Nasafi]. Kazan': Tatar. kn. izd-vo, 2008. 479 p.

[7] Khabibullin R. R. "Reformatorskie vzglyady G. Barudi" [The Reformed Views of G. Barudi]. Bigievskie chteniya: bogoslovskaya mysl' rossiyskikh musul'man XIXnach. XX vv.: sbornik nauchnykh statey. Moskva: Izdatel'skiy dom «Medina», 2015. P. 30-38.

[8] Shura, 1914. № 1. P. 1, 2.

[9] Kemper Mikhael'. "Mezhdu Bukharoy i Sredney Volgoy: stolknovenie abd an-Nasra al-Kursavi s ulemami traditsionalistami" [Between Bukhara and the Middle Volga: the clash of abd al-Nasra al-Kursavi with the ulama traditionalists]. Mir islama, 1999. № 1/2. P. 163-174. 
[10] Shagaviev Damir. "Bogoslovskiy traktat Shikhab ad-dina al-Mardzhani «Nazurat alkhakk»" [Theological treatise Shihab ad-din al-Mardzani "Nazurat al-haqq"]. Islam v sovremennom mire, 2016. T. 12. № 1. P. 41-48.

[11] Ad-din val'-adab, 1916. № 13. C. 347.

[12] Ad-din val'-adab, 1916. № 14. C. 380.

[13] Ad-din val'-adab, 1913. № 24. C. 742-744.

[14] Batyr Rustam. "Segodnya Galimdzhan Barudi vryad li by proshel attestatsiyu v DUM RT" ["Today, Galimdzan Barudi would hardly have passed the certification at the SAM of TR"]. Biznes-gazeta, 2017. 25 marta. https://www.business-gazeta.ru/blog/340899.

[15] Khabutdinov Aydar. "Kakim dolzhen byt' muftiy i ulem: primer Rizaetdina Fakhretdina (1858-1936)" [What should be the mufti and the ulama: the example of Rizaetdin Fakhretdin (1858-1936)]. Ramazanovskiy chteniya, 2010. № 5: http://www.idmedina.ru/books/history_culture/?3434\#_ftnref1.

[16] Gafarov A.A. Rossiyskie musul'mane v kontekste obshcheislamskoy modernizatsii (XIX - nachalo XX vv.) [Russian Muslims in the context of common Islamic modernization (XIX - early XX centuries)]. Kazan': Izd-vo Kazan. un-ta, 2014. 564 p.

[17] Fakhretdin Rizaetdin. Ibn Taymiyya [Ibn Taymiyyah]. Moskva: Forum, 2018. 231 p.

[18] Zarkone T. "Sufizm v tatarskom mire v nachale XX veka (Musa Yarulla Bigiev i odin iz polemicheskikh aspektov etoy problemy)" [Sufism in the Tatar world at the beginning of the 20th century (Musa Yarulla Bigiyev and one of the polemical aspects of this problem)]. Materialy mezhdunarodnogo simpoziuma «Islam v tatarskom mire: istoriya i sovremennost', Kazan', 29 aprelya - 1 maya 1996 g.: https://xn-80ad7bbk5c.xn--p1ai/ru/content/sufizm-v-tatarskom-mire-v-nachale-xx-veka.

[19] Musa Dzharullakh Bigiev. Izbrannye trudy v dvukh tomakh [Selected works in two volumes]. T. 1. Kazan': Tatar. kn. izd-vo, 2005. P. 235-326.

[20] Guseva Yu.N. Ishanizm kak sufiyskaya traditsiya Sredney Volgi v XX veke: formy, smysly, znachenie [Ishanism as a Sufi tradition of the Middle Volga in the 20th century: forms, meanings, meaning]. Moskva: ID «Medina», 2013. 214 p.

[21] Adigamov R.K. "Stanovlenie i razvitie bogoslovskoy mysli tatar: istoriya i tendentsii" [Formation and development of theological thought of the Tatars: history and tendencies]. Vestnik RUDN. Seriya: Istoriya Rossii, 2018. № 3. P. 551-580.

Научная статья

\section{Проблематика культа святых в трудах татарских богословов-джадидов конца XVIII - начала XX вв.}

\section{Э. Х. Сейдаметов}

Кафедра истории

ГБОУ ВО РК «Крымский инженерно-педагогический университет имени Февзи Якубова»

Россия, 295015 Симферополь, ул. Севастопольская; пер. Учебный, 8

Крымский научный центр Института истории им. Ш. Марджани АН РТ Россия, 420111, Казань, ул. Батурина, 7

Статья посвящена анализу проблематики культа святых в религиозных воззрениях крупнейших татарских богословов-джадидов конца XVIII - начала XX вв. В фокусе исследовательского интереса взгляды Габденнасыйра Курсави, Шигабутдина Марджани, 
Галимаджана Баруди, Ризаэтдина Фахретдина, Мусы Бигиева, которые искали причины комплексного упадка, охватившего мусульманские народы, и видели пути выхода из кризиса через исправление вероубеждения мусульман, отказ от новшеств в религии и возвращение к Священному Корану и Сунне. Они критиковали различные проявления невежества и суеверий, а также некоторые традиции, которые, по их мнению, шли вразрез с канонами ислама и являлись тормозом на пути к прогрессу мусульман. Джадиды выступали за реформирование системы образования, изучение мирских наук, заимствование и использование общемировых научно-технологических и иных достижений.

Подобная позиция татарских богословов должна была способствовать утверждению исламских культурных ценностей и открыть российским мусульманам новые пути для органичного приобщения к достижениям мировой цивилизации.

Ключевые слова: джадидизм, культ святых, тасаввуф (суфизм), бид’а (нововведение), таухид (единобожие), калам

\section{Информация об авторе / Information about the author}

Сейдаметов Эльдар Халилович - к.и.н., доц. кафедры истории ГБОУ ВО РК «Крымский инженерно-педагогический университет», заведующий Крымским научным центром Института им. Ш. Марджани АНРТ. E-mail: eseydamet@ bk.ru

Eldar Seidametov - Phd in history, Associate Professor of the Department of History of the State Budget Educational Institution of Higher Education of the Republic of Crimea Crimean Engineering Pedagogical University, Head of the Crimean Scientific Center of the Institute of History named after Sh. Marjani of the Academy of Sciences of the Republic of Tatarstan. E-mail: eseydamet@bk.ru

\section{Для цитирования / For citation}

Сейдаметов Э.X. Проблематика культа святых в трудах татарских богослововджадидов конца XVIII - начала XX вв. // Вестник Российского университета дружбы народов. Серия: Всеобщая история. 2019. Т. 11. № 4. С. 283-296. http://dx.doi.org/ 10.22363/2312-8127-2019-11-4-283-296

Seidametov E. Problematics of saints cult in works of jadidist-theolologians of the late XVIII and the early XX cc. // RUDN Journal of World History. 2019. Vol. 11. № 4. Pp. 283296. http://dx.doi.org/10.22363/2312-8127-2019-11-4-283-296

Рукопись поступила в редакцию / Article received: 22.11.2019 